\title{
Interaction Exchange in Dispensaries: An Observation on the Chronic Disease Management Program
}

\author{
Setiyo Budi Santoso ${ }^{1}$, Muhammad Hafid Naufal Majid², Annis Azhar Suryaningtyas ${ }^{3}$, \\ Rayinda Faizah ${ }^{4}$, Ika Mulyono Putri Wibowo ${ }^{5}$ \\ $\left\{\right.$ sb@unimma.ac.id $\left.{ }^{1}\right\}$ \\ Department of Community and Clinical Pharmacy, Universitas Muhammadiyah Magelang ${ }^{1}$ \\ Pharmacy Undergraduate Program, Universitas Muhammadiyah Magelang ${ }^{2}$ \\ Department of Communication Science, Universitas Muhammadiyah Magelang ${ }^{3}$ \\ Department of Clinical Psychology, Universitas Muhammadiyah Magelang ${ }^{4}$ \\ Department of Center Medication Information and Pharmaceutical Care, Universitas Surabaya ${ }^{5}$
}

\begin{abstract}
The number of chronic diseases in Indonesia has increased from year to year. One of the essential elements in managing chronic disease is the provision of adequate drug information. So pharmacists need to have excellent and practical communication skills when delivering drugs to chronic disease patients. This paper presents a process of exchange of interactions between pharmacists and patients in dispensaries. Researchers have collected data by cross-sectional observation in two primary health care. A total of 48 patients were involved in this study. The process of coding the interaction exchange has used the Roter Interaction Analysis System (RIAS). An interesting finding in the study was that most patients only took time from one minute when interacting with staff dispensaries. The mean number of interactions representing the task-focused function did not differ significantly between the two dispensaries during that duration. In contrast to social-emotional communication, the amount of information exchanged has a gap. Based on these findings, we recommend that future studies formulate specific guidelines for pharmacists for treating patients with chronic disease with a short duration.
\end{abstract}

Keywords: Primary Health Care, Roter Interaction Analysis System, Task focused, Socioemotional

\section{Introduction}

The prevalence of hypertension and type 2 diabetes mellitus (T2DM) has increased in Indonesia. The hypertension population was $25.8 \%$ (2013), rising to $34.1 \%$ (2018). Likewise, the T2DM population was rising from $6.9 \%$ (2013) to $8.5 \%$ (2018) [1]. Through the chronic disease management program (Prolanis), they obtain health services proactively from health facilities that were integrated with the national health insurance as called by BPJS [2].

Prolanis participant adherence in taking medication is the key to successful therapy management [3]; [4]. Their adherence to therapy is closely related to drug counselling services by pharmacist [5]-[8].

Sari, Putra, \& Masran state that patients with good knowledge have a high need for drug information. Some patients tend to hesitate to ask questions to pharmaceutical personnel [10]. One reason is the lack of perceptions of patients towards health workers due to poor communication [11]. 
Prolanis participants have increased from year to year. Some researchers have concluded the relationship between drug information services on the quality of therapy management output of prolanis participants. However, many prolanis participants are still constrained in obtaining optimal drug information services. The author considers it necessary to formulate a good communication model in therapy management. To initiate the development roadmap. Through this paper, the authors identify the interaction process in dispensaries that involves pharmacist and prolanis participants.

\section{Method}

This research took place at two primary health care (PHC), Unit Tempuran and Unit Muntilan 2. Both are first-level health facilities in Magelang Regency-Indonesia, integrated into the national health insurance service (BPJS).

The cross-sectional observations have taken place while participants were visiting each PHC on their monthly schedule (February 2020). Through an audio recording device, we recorded all interactions that took place in a pharmaceutical service expressly provided for prolanis participants. Forty-eight participants (26 members of Unit Muntilan and 22 members of unit Tempuran) were involved in the study. All steps in the series of methods have received approval from the head of the Magelang district health office, pharmaceutical personnel and prolanist participants involved in the research.

All recordings are then transcribed in text. Furthermore, we analyzed it according to the Roter Interaction Analysis System (RIAS) instrument [12]. The procedure is carried out under the fifth author's direction, as an experienced and verified researcher who has successfully carried out this method in previous research [13], [14]. The coding results were descriptively presented in two types to the communication functions: task-focused and socio-emotional.

\section{Results and Discussion}

\subsection{Result}

Based on our observations, we reported that most prolanis participants only took a short time when interacting with staff dispensaries. The average interaction time in PHC Tempuran was only 35 seconds, along with in PHC Muntilan 2 for 40 seconds (figure 1). During the duration, the mean number of interactions representing the task-focused function was balanced in both of PHC, amounting to 5.7 utterances. In contrast to socio-emotional communication, the amount of information exchanged has a gap. The mean interaction in the PHC Tempuran was less with 4.12 utterances, whereas, in PHC Muntilan 2, the mean was 6.64 utterances which were moreover (figure 1). 


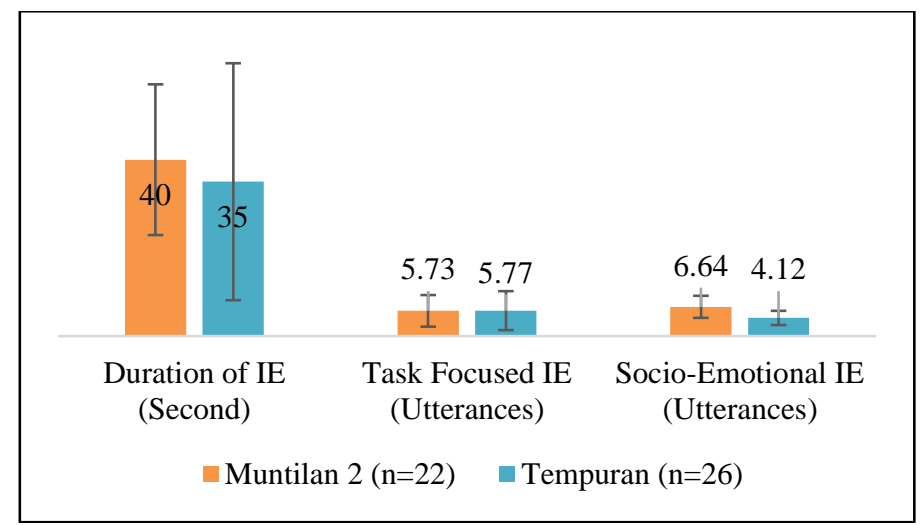

Fig. 1. Mean duration and utterances of interactions exchange (IE) between patient and pharmacist in dispensaries

Table 1 showed the utterances domains involved in exchange interactions. We are interested in writing down the number of interactions that are predominantly interchangeable. What is at the top is precisely biomedical information that is not related to the therapeutic regimens. This statement is confirmed by giving information with 159 utterances and pharmacists' efforts in gathering data with 39 closed questions and 33 open questions. The domains are evenly distributed in the two dispensaries.

The most frequent interaction with therapeutic regimens was the provision of information with a total of 17 utterances. Moreover, therapeutic domains are rarely explored with either closed-ended questions (6 utterances), or open-ended questions (3 utterances).

Table 1. The frequency of utterances representing a task-focused interaction

\begin{tabular}{|c|c|c|c|c|}
\hline No & Variables of Interaction Exchange & $\begin{array}{c}\text { PHC } \\
\text { Muntilan 2 } \\
(\mathrm{n}=22)\end{array}$ & $\begin{array}{c}\text { PHC } \\
\text { Tempuran } \\
(\mathrm{n}=26)\end{array}$ & $\begin{array}{c}\text { Total } \\
(\mathrm{n}=48)\end{array}$ \\
\hline 1. & $\begin{array}{lll}\text { Give information } & \text { on } & \text { other } \\
\text { therapeutic regimen }\end{array}$ & 79 utterances & 80 utterances & 159 utterances \\
\hline 2. & $\begin{array}{l}\text { Ask closed-ended question on other } \\
\text { therapeutic regimen }\end{array}$ & 20 utterances & 19 utterances & 39 utterances \\
\hline 3. & $\begin{array}{l}\text { Give information on therapeutic } \\
\text { regimen }\end{array}$ & 13 utterances & 20 utterances & 33 utterances \\
\hline 4. & $\begin{array}{l}\text { Ask open-ended question on other } \\
\text { therapeutic regimen }\end{array}$ & 7 utterances & 10 utterances & 17 utterances \\
\hline 5. & $\begin{array}{l}\text { Ask closed-ended question on } \\
\text { therapeutic regimen }\end{array}$ & 3 utterances & 3 utterances & 6 utterances \\
\hline 6. & $\begin{array}{l}\text { Ask open-ended question on } \\
\text { therapeutic regimen }\end{array}$ & 2 utterances & 1 utterance & 3 utterances \\
\hline 7. & Give Orientation/Instruction & 1 utterance & 4 utterances & 5 utterances \\
\hline 8. & Ask for understanding & No utterance & 5 utterances & 5 utterances \\
\hline 9. & Ask for permission & No utterance & 2 utterances & 2 utterances \\
\hline 10. & Bid for repetition & 1 utterances & 1 utterance & 2 utterances \\
\hline 11. & Back Channel & No utterance & 1 utterance & 1 utterance \\
\hline
\end{tabular}


Other domains (table 1) that are slightly discussed are those related to orientation (5 utterances), ask for understanding ( 5 utterances), ask for permission ( 2 utterances), bid for repetition ( 2 utterances) and only one utterance on the backchannel.

A report on interactions that represent socio-emotional functions is presented in Table 2. We are amazed to see that this interaction is dominated by a show of agreement (understanding) with 94 utterances and approval direct with 84 utterances. Efforts to ensure patients' identity in pharmaceutical services are indicated by the number of personal remarks, as many as 66 utterances, which is evenly distributed in both dispensaries.

Among the three dominant domains, what appears to be a gap in the two dispensaries is the approval performance. Prolanis members in PHC Tempuran are more expressive in the making than the members in PHC Muntilan 2.

Table 2. The frequency of utterances representing a socio-emotional interaction

\begin{tabular}{lllll}
\hline No & Variables of Interaction Exchange & $\begin{array}{c}\text { PHC } \\
\text { Muntilan 2 } \\
(\mathrm{n}=22)\end{array}$ & $\begin{array}{c}\text { PHC } \\
\text { Tempuran } \\
(\mathrm{n}=26)\end{array}$ & $\begin{array}{c}\text { Total } \\
(\mathrm{n}=48)\end{array}$ \\
\hline 1. & Show agreement or understanding & 44 utterances & 50 utterances & 94 utterances \\
2. & Show approval-direct & 27 utterances & 57 utterances & 84 utterances \\
3. & Personal remarks & 33 utterances & 33 utterances & 66 utterances \\
4. & Laughs, tells jokes & 1 utterance & 5 utterances & 6 utterances \\
5. & Shows disapproval-direct & 1 utterance & No utterance & 1 utterance \\
6. & Back channel responses & 1 utterance & 1 utterance & 2 utterances \\
\hline
\end{tabular}

There are not many attempts at cracking the situation through talks of jokes or laughs (6 utterances). Among patients and staff, there were also almost no statements of denial (1 utterance). Backchannel expression was responded to only once in each dispensary.

\subsection{Discussion}

In previous publications, we have described pharmacists' readiness and responsiveness in providing excellent service in dispensaries[15], [16]. This paper presents the facts of the interactions exchange at PHC. This data is notable for three reasons. First, this is the roadmap opening gate for developing a communication model in Indonesia pharmaceutical services that we are currently doing. Second, identifying communication using RIAS instruments in a pharmaceutical context has never been done in a PHC setting. Third, we studied populations with chronic diseases who regularly attend health system services, including pharmaceutical services.

Publications on drug information services, particularly in the setting of PHC in Indonesia, evaluate drug administration, which includes services regarding name, dose, time, frequency and similar matters regarding the procedure for taking drugs [17]-[19]. Although they have proven that aspects of drug information services are beneficial for patients in terms of compliance, achieving therapeutic results, improving knowledge, to satisfaction [4], [20]-[25]. However, we consider that a more detailed stage is needed to reconstruct what has happened in dispensaries' interactions so far. For this reason, we use the RIAS instrument in completing this research design.

Our findings confirm that both dispensaries have a balanced number of interaction exchanges on the task-focused aspect. It is an effort to ensure that the patient's steps in taking drugs are safe. Moreover, the pharmacy staff is responsible for helping patients solve problems 
related to drugs. In the Indonesian context, this is the case in pharmacy and medical services. Sure, the minimum standard for providing health services information is information about biomedicine [26]. Regarding the pharmacy, task-focused. In our findings, we highlighted that much interaction spent demanding complete insurance administration. So we think it is evident to explain the many frequencies of interactions exchange in another therapeutic regimen.

However, the mean of frequencies to the socio-emotional interaction has gaps between the two dispensaries. Even so, Table 3 confirms that a high gap occurs in the approval performance. The author considers this is not worthwhile. What should be appreciated is the high dealing expression between patients and pharmacists. It shows that they are in the form of agreement, understanding or approval. Almost no disapproval performances between them also supported this. Even so, the socio-emotional has improved engagement between patients and pharmacy staff [27]. In other findings, the socio-emotional interaction is even more practised by patients [14]

Beyond our expectations, it turns out that prolanis members spend less than 1 minute interacting in dispensaries. It is surprising. In another setting, They take 20-30 minutes to maximize counselling in each meeting [28]. Other opinions express that the setting can be the cause of less than optimal communication [29]. The researchers' observations show that the PHC has met the waiting room standards according to the regulations [30]. Even so, patients encounter several challenges in accessing services at PHC. Patients need to spend plenty of time queuing before facing a doctor. Then queue while waiting for a call from the pharmacy service. Many of them thought about going home immediately after receiving the medicine. As for the prolanis members we observed, they were already familiar with the drugs they routinely took for a long duration.

Our experience shows that patients with chronic disease who have been taking medication for a long duration need a touch of socio-emotional communication as motivation in undergoing therapy [31]. Research on pharmaceutical communication should be developed further to intervene in the dimensions of patient quality of life or the problem of drug therapy intervention as we have partly investigated [32], [33]. The result of this research is the incomplete puzzle pieces. We will immediately submit research data on another setting as drugstores and hospitals. Our steps have strong analytical materials to develop a suitable communication model to be a reference for pharmacists in Indonesia.

\section{Conclusion}

Our findings confirm that prolanis members spend less time interacting with pharmacists. The prolanis participants were familiar with the issues related to the drugs they were taking. We recommend that future studies formulate specific guidelines for pharmacists for treating patients with chronic disease with a short duration.

\section{Acknowledgement}

We would like thanks to the Research Division of Universitas Muhammadiyah Magelang through the funding research grant scheme of institutional vision revitalization in 2019. 


\section{References}

[1] Riskesdas, 'Hasil Utama Riskesdas 2018'. 2018.

[2] Badan Pengelola Jaminan Sosial Kesehatan, Peraturan Badan Penyelenggara Jaminan Sosial Kesehatan Nomor 2 Tahun 2019 Tentang Pelaksanaan Skrining Riwayat Kesehatan Dan Pelayanan Penapisan Atau Skrining Kesehatan Tertentu Serta Peningkatan Kesehatan Bagi Peserta Penderita Penyakit Kronis Dalam Program Jaminan Kesehatan. 2019, p. 16.

[3] K. Idacahyati, 'Peningkatan Kepatuhan Pasien Hipertensi Dengan Pemberian Informasi Obat', J. Kesehat. Bakti Tunas Husada J. Ilmu-Ilmu Keperawatan Anal. Kesehat. Dan Farm., vol. 17, no. 2, p. 243, Mar. 2018, doi: 10.36465/jkbth. v17i2.228.

[4] S. W. Dewanti, R. Andrajati, and S. Supardi, 'Pengaruh Konseling dan Leaflet terhadap Efikasi Diri, Kepatuhan Minum Obat, dan Tekanan Darah Pasien Hipertensi di Dua Puskesmas Kota Depok', J. Kefarmasian Indones., vol. 5, no. 1, pp. 33-40, May 2015, doi: 10.22435/jki. v5i1.4088.33-40.

[5] A. P. Sisca, 'Pemgaruh Konseling dalam Kegiatan Prolanis Terhadap Kepatuhan Pengobatan Pasien Diabetes Melitus Tipe 2 Puskesmas Grogol Sukoharjo', p. 138, 2016.

[6] H. Nadia, A. T. Murti, and W. Chairun, 'Pengaruh Konseling Farmasis Terhadap Kepatuhan Penggunaan Obat Serta Hasil Terapi Pasien Diabetes Melitus Tipe 2 di Puskesmas’, p. 8, 2017.

[7] M. Dewi, I. P. Sari, and Probosuseno, 'The Influence of The Pharmacists Counseling on Patient Adherence and Hypertension Control on Patient of Prolanis at Mitra Husada Clinics', Indones. J. Clin. Pharm., vol. 4, no. 4, pp. 242-249, Dec. 2015, doi: 10.15416/ijcp.2015.4.4.242.

[8] A. Megawati, 'Pentingnya Manajemen Pelayanan Penggunaan Obat dan Edukasi Dalam Pengendalian Kadar Gula Darah Pada Pasien Diabetes Melitus', vol. 1, no. 4, p. 17, 2015.

[9] R. P. Sari, A. M. P. Putra, and U. Masran, 'Hubungan Pengetahuan dan Kebutuhan Pasien Terhadap Informasi Obat di Apotek Amandit Farma Banjarmasin', p. 8, 2018.

[10] T. S. Hartayu, Y. Wijoyo, and L. W. Wijayanti, 'Pemahaman Masyarakat Kecamatan Mergangsan, Gondokusuman, Umbulharjo dan Kotagede Yogyakarta Terkait Antibiotika', p. 7, 2013.

[11] E. E. Hutagaol, 'Komunikasi Interpersonal Petugas Kesehatan Dalam Kegiatan Posyandu di Wilayah Kerja Puskesmas Muara Siberut Kabupaten Mentawai', J. Kesehat. Masy., vol. 6, p. 9, 2012.

[12] A. Cavaco and D. Roter, 'Pharmaceutical Consultations in Community Pharmacies: Utility of the Roter Interaction Analysis System to Study Pharmacistpatient Communication', Int. J. Pharm. Pract., vol. 18, pp. 141-148, 2010.

[13] I. Mulyono, S. Irawati, A. Pratidina, and M. Claramita, 'Patient-Pharmacist Communication: an Observasional Study of Characteristic Information', in Unity in Diversity and the Standardisation of Clinical Pharmacy Services, Yogyakarta, Dec. 2017, pp. 167-170, doi: 10.1201/9781315112756.

[14] I. Mulyono, S. Irawati, A. P. Susilo, and M. Claramita, 'Pharmacist-Patient Communication in Indonesia: The Roter Interaction Analysis System (rias) in a Socio- Hierarchical Context', Pharm. Educ., vol. 19, no. 1, pp. 359-369, 2019.

[15] H. Lutfiyati, P. Pribadi, and S. B. Santoso, 'Kesiapan Apoteker dalam Memberikan Layanan Medication Therapy Management', CERATA J. Ilmu Farm., vol. 10, no. 1, p. 5, 2019.

[16] H. Lutfiyati, B. Mintarsih, S. B. Santoso, and D. K. Dewi, 'Evaluasi Sumber Daya Apoteker Berdasarkan Standar Pelayanan Kefarmasian Terkait Sumber Daya Manusia di Apotek Kabupaten Temanggung', presented at the Prosiding Pertemuan Ilmiah Daerah IAI PD Jawa Tengah 2020, Surakarta, Indonesia, 2020.

[17] R. Adityawati, E. Latifah, and W. S. Hapsari, 'Evaluasi Pelayanan Informasi Obat pada Pasien Rawat Jalan di Instalasi Farmasi Puskesmas Grabag I’, J. Farm. Sains Dan Prakt., vol. 1, no. 2, pp. 6-10, 2016.

[18] A. Priyanto, M. Hasanmihardja, and D. Setiawan, 'Pelaksanaan Penyimpanan Obat dan Pelayanan Informasi Obat kepada Pasien di Puskesmas di Kota Purwokerto', Pharmacy, vol. 7, no. 3, pp. 93$106,2010$.

[19] S. Supardi, Raharni, A. L. Susyanti, and M. J. Herman, 'Evaluasi Peran Apoteker Berdasarkan Pedoman Pelayanan Kefarmasian di Puskesmas', Media Litbang Kesehat., vol. 22, no. 4, pp. 190 198, 2012. 
[20] G. Fadhila, 'Pengaruh Konseling Terhadap Kepatuhan Pasien Hipertensi di Salah Satu Puskesmas di Kota Bandung', Farm. Bahari, vol. 10, no. 1, pp. 1-8, 2019.

[21] Rr. S. L. Hanggara, N. C. Gibran, A. M. Kusuma, and G. F. Galistiani, 'Pengaruh Keberadaan Apoteker terhadap Mutu Pelayanan Kefarmasian di Puskesmas Wilayah Kabupaten Banyumas', J. Kefarmasian Indones., vol. 7, no. 1, pp. 67-76, 2017.

[22] A. Kurniapuri and W. Supadmi, 'Pengaruh Pemberian Informasi Obat Antihipertensi Terhadap Kepatuhan Pasien Hipertensi di Puskesmas Umbulharjo I Yogyakarta Periode November 2014', Maj. Farm., vol. 11, no. 1, pp. 268-274, 2015.

[23] G. W. Pratama and N. L. P. Ariastuti, 'Faktor - Faktor yang Mempengaruhi Kepatuhan Pengobatan Hipertensi pada Lansia Binaan Puskesmas Klungkung 1', E-J. Med. Udayana, vol. 5, no. 1, pp. 1$13,2016$.

[24] H. E. Septiar and P. Utami, 'Pengaruh Konseling Farmasis Terhadap Kualitas Hidup dan Kadar Gula Darah pada Pasien Diabetes Mellitus Tipe 2 di Puskesmas Gedong Tengen Periode Maret-Mei 2014', J. Farm. Sains Dan Prakt., vol. 1, no. 1, pp. 29-35, 2015.

[25] N. A. Susanto, M. Mansur, and T. Djauhari, 'Analisis Kebutuhan Tenaga di Instalasi Farmasi RS Universitas Muhammadiyah Malang Tahun 2016', J. Medicoeticolegal Dan Manaj. Rumah Sakit, vol. 6, no. 2, pp. 82-89, 2017, doi: 10.18196/jmmr.6131.

[26] M. Claramita, J. Van Dalen, and C. P. Van Der Vleuten, 'Doctors in a Southeast Asian Country Communicate Sub-Optimally Regardless of Patients' Educational Background', Patient Educ. Couns., vol. 85, no. 3, pp. e169-e174, 2011, doi: 10.1016/j.pec.2011.02.002.

[27] C. Naughton, 'Patient-Centered Communication', Pharmacy, vol. 6, no. 1, p. 18, Feb. 2018, doi: 10.3390/pharmacy6010018.

[28] R. G. Aurora, A. Sinambela, and C. H. Noviyanti, 'Peran Konseling Berkelanjutan pada Penanganan Pasien Hiperkolesterolemia', J. Indones. Med. Assoc., vol. 62, no. 5, pp. 194-201, 2012.

[29] A. M. Cavaco, 'Patient Education and Counseling Exploring pharmacists' communication with customers through screening services', vol. 80, pp. 377-383, 2010.

[30] Peraturan Menteri kesehatan Nomor 74 Tahun 2016 tentang Standar Pelayanan Kefarmasian di Puskesmas. 2016.

[31] S. B. Santoso, H. Lutfiyati, R. I. Prasidha, S. Ratnafuri, and K. A. Azzahra, 'What do patients with HIV-infection perceive and know regarding to antiretrovirals? An exploration among participants undergoing controlled-therapy', Technol. Rep. Kansai Univ., vol. 62, no. 04, p. 7, 2020.

[32] S. B. Santoso, D. A. Perwitasari, I. N. Faridah, and A. A. Kaptein, 'Hubungan Kualitas Hidup Dan Persepsi Pasien Tentang Penyakit Diabetes Mellitus Tipe 2 Dengan Komplikasi’, Pharmaciana, vol. 7, no. 1, p. 33, 2017, doi: 10.12928/pharmaciana. v7i1.4699.

[33] S. B. Santoso and M. Azalea, 'Potensi Interaksi Antibiotik dengan Obat Penyerta pada Peresepan Pasien ISPA Dan PPOK', CERATA J. Ilmu Farm., vol. 9, no. 1, p. 8, 2018. 